\title{
Color of smoked loin from animals fed with bioactive compounds added to forage
}

\author{
Dominika Guzek(1), Dominika Głąbska ${ }^{(2)}$, Anna Sakowska ${ }^{(1)}$ and Agnieszka Wierzbicka(1)
}

\begin{abstract}
(1)Warsaw University of Life Sciences (WULS), Faculty of Human Nutrition and Consumer Sciences, Department of Functional Food and Commodities, 159C Nowoursynowska Street, 02-776 Warsaw, Poland. E-mail: dominika_guzek@sggw.pl, anna_sakowska1@sggw.pl, agnieszka_wierzbicka@sggw.pl (2)WULS, FHNCS, Department of Dietetics. E-mail: dominika_glabska@sggw.pl
\end{abstract}

Abstract - The objective of this work was to evaluate the influence of the breed and of the addition of bioactive substances to forage on the color of smoked pork loin. Two pig breeds (Polish Landrace and the crossbreed Polish Landrace x Duroc), three types of bioactive components (organic selenium; $2 \%$ of canola oil and 1\% of flaxseed oil; and $2 \%$ of flaxseed oil and $1 \%$ of canola oil), and a control treatment were evaluated. Computer image analysis included the color assessment of muscle, fat, connective tissues, and smoked loin surface. For Polish Landrace, selenium supplementation caused higher values of red, green, and blue color components of the muscle tissue, which were lower for the crossbreed. However, there was no difference in the color components of loin fat tissue of the Polish Landrace breed due to selenium supplementation. In the case of oil supplementation, values of the color components of the muscle tissue for the Polish Landrace $\mathrm{x}$ Duroc crossbreed were also lower. The color components of muscle, fat, connective tissues, and smoked loin surface depend on the pig breed and on the bioactive compounds added to the forage.

Index terms: Sus scrofa f. domestica, canola oil, computer image analysis, flaxseed oil, functional food, selenium-enriched meat.

\section{Cor do lombo defumado de animais alimentados com substâncias bioativas acrescentadas à forragem}

\begin{abstract}
Resumo - O objetivo deste trabalho foi avaliar a influência da raça e da adição de substâncias bioativas à forragem sobre a cor do lombo defumado de porco. Foram avaliados: duas raças de porcos (Landrace Polonesa e o cruzamento Landrace Polonesa x Duroc), três tipos de componentes bioativos (selênio orgânico; $2 \%$ de óleo de canola e $1 \%$ de óleo de linhaça; $2 \%$ de óleo de linhaça e $1 \%$ de óleo de canola) e um tratamento controle. A análise de imagem por computador incluiu a avaliação da cor dos tecidos muscular, gorduroso e conjuntivo e da superfície defumada do lombo. Na raça Landrace Polonesa, a suplementação com selênio promoveu aumento dos valores das cores vermelha, verde e azul do tecido muscular, que foram inferiores no cruzamento Landrace Polonesa x Duroc. Contudo, não foram observadas diferenças significativas nas cores do tecido gorduroso do lombo da raça Landrace Polonesa em razão da suplementação com selênio. No caso da suplementação com óleos, os valores das cores integrantes do tecido muscular também foram inferiores no cruzamento Landrace Polonesa x Duroc. As cores integrantes dos tecidos muscular, gorduroso e conjuntivo e da superfície defumada do lombo dependem da raça dos porcos e das substâncias biotivas acrescentadas à forragem.
\end{abstract}

Termos para indexação: Sus scrofa f. domestica, óleo de canola, análise de imagens computadorizadas, óleo de linhaça, alimento funcional, carne enriquecida com selênio.

\section{Introduction}

Currently, there is an increasing demand for functional foods (Kapsak et al., 2011), including meat products. The knowledge acquisition on the consequences of improper diets (Jiménez-Colmenero et al., 2010) has played a role in this. One of the main factors that can cause the development of diet-related diseases is the overconsumption of animal fat, which is an important source of cholesterol and saturated fatty acids, associated with the low intake of other nutrients (Polychronopoulos et al., 2010).

This scenario may lead to changes in the diet structure and in the consumer preferences, such as a reduction in the consumption of meat - especially red ones (Singh et al., 2003). Functional meat products based on bioactive components may be a possible solution for producers, especially if innovative technologies that simultaneously assure typical sensory features and health-promoting components are used (Siró et al.,

Pesq. agropec. bras., Brasília, v.47, n.10, p.1504-1510, out. 2012 
2008). These technologies are characterized by the addition of specific substances, with proven functional value, to animal feed. These substances may have an effect on limiting the risk of diet-related diseases, and should not cause differences in terms of sensory qualities and nutrient content of the meat (Doyon \& Labrecque, 2008). Bioactive compounds are being researched as supplements in pig diets in order to obtain health benefits for consumers by, for example, changing fatty acid composition (Juárez et al., 2010) or incorporating selenium into the produced meat (Mahan et al., 1999).

Bioactive components, such as fibers, probiotics, prebiotics, unsaturated fatty acids, vitamins, and trace elements (as selenium) or other minerals are commonly used in the production of functional meat (Bhat \& Bhat, 2011). These components may be added as pure substances (Morin et al., 2004) or as part of other ingredients, characterized by high levels of the functional component (Jiménez-Colmenero et al., 2010). Bioactive components may be added to the forage during animal breeding (Joy et al., 2012) or during the production of meat products (Josquin et al., 2012). The creation of these new products, with functional properties, should be controlled to guarantee their safety and functional value, and to ensure that they are accepted by the consumers (Verbeke, 2006).

In the case of meat and its products, the most desirable quality feature for the consumer is the appearance of the product, especially its color (Tan, 2004). If the color is not accepted by the consumers, the other features are no longer important and the whole product is rejected (Iqbal et al., 2010). Therefore, the assessment of the effects of bioactive components on color is very important, since it is determinant in the perceived freshness of meat and also in its overall quality (Grunert et al., 2004).

The objective of this work was to evaluate the influence of the breed and of the addition of bioactive substances to forage on the color of smoked pork loin.

\section{Materials and Methods}

The experiment was carried out in laboratory, at the Warsaw University of Life Science, Poland, in 2011. The evaluated smoked pork loin was produced from ten Polish Landrace and 20 crossbreed Polish Landrace $\mathrm{x}$ Duroc animals, obtained in the project "Biofood - innovative, functional products of animal origin", co-financed by the European Union, from the European Regional Development Fund, within the Innovative Economy Operational Programme (2007-2013). Five Polish Landrace animals were fed control forage, and five were fed forage with $1.0 \mathrm{mg} \mathrm{kg}^{-1}$ of organic selenium. Five Polish Landrace $\mathrm{x}$ Duroc animals were fed control forage, five forage with $1.0 \mathrm{mg} \mathrm{kg}^{-1}$ of organic selenium, five forage with $2 \%$ of canola oil and $1 \%$ of flaxseed oil (Can_flax), and five forage with $2 \%$ of flaxseed oil and 1\% of canola oil (Flax_can). The composition of the experimental diets (Table 1) was determined according to the Association of Analytical Chemists methods (Cuniff, 1997). The metabolizable energy values of the experimental diets were calculated as follows (Alderman, 1985): metabolizable energy $\left(\mathrm{ME}, \mathrm{MJ} \mathrm{kg}^{-1}\right)=11.78+0.00654 \mathrm{CP}+(0.000665 \mathrm{EE})$ - $\mathrm{CF}(0.00414 \mathrm{EE})-0.0118 \mathrm{~A}$, in which: $\mathrm{CP}$ is the crude protein; $\mathrm{EE}$ is the ether extract; $\mathrm{CF}$ is the crude fiber; and $\mathrm{A}$ is the ingredient ash (dry matter basis).

Smoked pork loin was produced from the meat of these six groups of animals (five pigs of the same sex), using the typical production process: weighing of the loin, curing (injecting with brine solution), plasticization (rubbing with residual brine solution), cording, hanging $\left(30^{\circ} \mathrm{C}\right.$ for 2 hours), smoking (surface drying with air at $30^{\circ} \mathrm{C}$ and smoking for $1.5-24$ hours with smoke at $25-40^{\circ} \mathrm{C}$ ), thermal treatment (roasting for $20 \mathrm{~min}$ at $80-85^{\circ} \mathrm{C}$ until reaching internal temperature of $60^{\circ} \mathrm{C}$ ), and cooling to an inside temperature below $10^{\circ} \mathrm{C}$. The loins were packed and

Table 1. Forage composition of the control treatment.

\begin{tabular}{lc}
\hline Ingredient & Control \\
\hline Barley grits & 360 \\
Wheat middlings & 360 \\
Corn grits & 100 \\
Extracted rapeseed meal & 40 \\
Extracted soybean meal & 80 \\
Premix vitamin minerals & 25 \\
\hline Chemical composition & \\
$\quad$ Dry matter $\left(\mathrm{g} \mathrm{kg}^{-1}\right)$ & 903 \\
Ash $\left(\mathrm{g} \mathrm{kg}^{-1}\right)$ & 22 \\
Organic matter $\left(\mathrm{g} \mathrm{kg}^{-1}\right)$ & 881 \\
$\quad$ Crude protein $\left(\mathrm{g} \mathrm{kg}^{-1}\right)$ & 161 \\
Digestible protein $\left(\mathrm{g} \mathrm{kg}^{-1}\right)$ & 139 \\
Crude fiber $\left(\mathrm{g} \mathrm{kg}^{-1}\right)$ & 38 \\
Compounds without the N exhaust $\left(\mathrm{g} \mathrm{kg}^{-1}\right)$ & 603 \\
Metabolizable energy $(\mathrm{MJ} \mathrm{kg} \mathrm{of} \mathrm{dry} \mathrm{matter)}$ & 13.5 \\
\hline
\end{tabular}

Pesq. agropec. bras., Brasília, v.47, n.10, p.1504-1510, out. 2012 
stored for the same time in identical conditions, i.e., typical market conditions, until analysis.

Computer image analysis of the surface of smoked pork loin was done according to Zheng et al. (2006) and Guzek et al. (2012), with adaptations, $30 \mathrm{~min}$ after removing the meat from the packages and cutting it into $2.54 \mathrm{~cm}$ thick slices. Computer image analysis included color assessment of muscle, fat, connective tissues, and smoked surface. For the 108 samples evaluated (18 for each kind of smoked pork loin), surface images were acquired for two slice surfaces and for the smoked loin surface. Digital color images were taken using a real-time viewing camera Micropublisher 5.0, (QImaging, Surrey, BC, Canada) and Dulux L 36W/954 (Osram, München, Germany) fluorescent lamps. For each sample and tissue, 20 pixels were randomly selected. For each of the chosen pixels, the color was determined using the Image-Pro Plus 7.0 software (Media Cybernetics, Rockville, MD, USA) in the red-green-blue (RGB) color scheme. The software was previously calibrated against a standard white reference tile. The red, green, and blue component values were collected for all the pixels. Mean values with standard deviation were calculated for all the samples.

Fat content was determined by the method described in PN ISO 1444 (International Organization for Standardization, 2000). Standard procedures for fatty acid composition were determined according to the Association of Analytical Chemists methods (Cuniff, 1997). Results were given as fatty acid profiles. The following were calculated: total of saturated fatty acids (SFA), monounsaturated fatty acids (MUFA), polyunsaturated fatty acids (PUFA), and, separately, the sum of PUFA n- 6 and PUFA n-3. In addition, for comparison, the n-6 to n-3 ratio was calculated. Fatty acids were analyzed in homogenized samples using the methyl ester method (Folch et al., 1957). Methyl esters of fatty acids were separated by gas chromatography on a Trace GC ultra chromatograph (Thermo Scientific, Madison, WI, USA), equipped with a RT 2560 RESTEC capillary column $(100 \mathrm{~m} \times 0.25 \mathrm{~mm} \times 0.2 \mu \mathrm{m})$, with helium as a carrier gas. The high polarity phase was biscyanopropyl polysiloxane. The temperature range was from 20 to $250^{\circ} \mathrm{C}$.

Selenium content was determined using atomic emission spectroscopy with plasma [ICP-AES] excitation. Plasma parameters were: $1,200 \mathrm{~W}$ power;
$12 \mathrm{~L}^{-1}$ per min of plasma gas; $0.3 \mathrm{~L}^{-1}$ per min of auxiliary gas; $0.4 \mathrm{~L}^{-1}$ per min of sample gas; $8 \mathrm{~mm}$ of viewing height; $14 \mathrm{rpm}$ of pump speed; and $700 \mathrm{~V}$ of PMT voltage. The principle of the method is measuring the electromagnetic radiation emitted by the atoms of the element contained in the sample after introducing it into the argon plasma. Radiation intensity, which is directly proportional to the concentration of the element in the sample, was also determined.

To characterize the relationships between the analyzed factors, analysis of variance and Scheffe's post-hoc test were used, at 5\% probability. Statistical analysis was done using the Statistica software version 8.0 (StatSoft, Tulsa, OK, USA).

\section{Results and Discussion}

The characteristics of the analyzed smoked pork loin are shown in Table 2. Significant influence of forage was observed for red, green, and blue color components of the muscle tissue (Table 3). The combined effect of breed and forage was also significant. Post-hoc analysis allowed for sample comparison and for the analysis of the influence of selenium and oil supplementation. The same analyses were conducted for fat tissue, connective tissue, and smoked surface of pork loin.

The influence of selenium supplementation on color components was mainly observed in the muscle tissue (Table 3). Color changes were strongly associated with the breed. Supplementation increased color components of muscle in the Polish Landrace, and reduced it in the Polish Landrace x Duroc. Since the control group of Polish Landrace had lower values of color components than the Polish Landrace x Duroc, the color of the muscle in the first was comparable with the color of the Polish Landrace $\mathrm{x}$ Duroc selenium sample. Therefore, the color of the muscle tissue was influenced by selenium supplementation and moderated by the breed.

Contradictory results are reported in the literature. Mateo et al. (2007) and Svoboda et al. (2009) found no significant differences in color characteristics with selenium supplementation on the meat loin muscle tissue of Camborough x PIC boar and on the biceps femoris muscle of Landrace $\mathrm{x}$ Czech Large White crossbreeds. However, Mahan et al. (1999) observed linear response to applied doses of selenium in the diet of an unspecified breed of pigs, when measuring 
lightness ( $\mathrm{L}^{*}$ color component), with $\mathrm{L}^{*}$ increasing with the selenium dose. Our results show that these differences are probably associated to the breeds. Moreover, in those previous studies, the analyzed material was meat, whereas in the present work it was smoked pork loin. Meat products are characterized by different quality features than those of meat, even when the same cut is used, as observed for loin in the studies of Mahan et al. (1999) and Mateo et al. (2007). According to other authors (Poovey et al., 2007), the lack of influence of selenium supplementation on meat color could be associated with time and temperature conditions after slaughter, which might not allow oxidation to influence the color.

For the fat and connective tissues, no significant differences due to supplementation were observed for the Polish Landrace (Table 3). The same result was observed for the red color component of fat tissue in the Polish Landrace $x$ Duroc. For the rest of the color components of the fat and connective tissues of Polish Landrace $\mathrm{x}$ Duroc, the differences were similar to those for muscle tissue. Moreover, color components of the fat and muscle tissues of smoked pork loin from the Polish Landrace $\mathrm{x}$ Duroc were lower with selenium supplementation.

The quantity of selenium in the loin is strongly correlated with the amount of selenium in the diet (Mahan et al., 2005). Therefore, the addition of selenium to the forage, changing the composition of the loin, may simultaneously modify the characteristics of the element and the color of the muscle tissue. The influence of selenium supplementation on drip loss (Mahan et al., 1999) and on loin weight was also reported (Mateo et al., 2007). As a result, changes on fat and connective tissue characteristics may be observed. These changes are expected, especially in the case of fat tissue, as selenium supplementation in pig diets enhances the antioxidant status (Zhan et al., 2007).

In the case of smoked loin surface, the influence of selenium on color components was observed only in the Polish Landrace, with higher red and green values, similarly to the changes for muscle tissue (Table 3 ). Krause et al. (2007) found no influence of selenium supplementation on the color of pork loin chops (breed not specified) after the smoking process, which, as previously mentioned, may be dependent on several other factors.

The influence of fat supplementation on the color components of muscle tissue was observed in the Flax_canola samples, for all color components, and for the green and blue components in the Canola_flax samples (Table 3). Therefore, not only the quantity of the fat content is important - which was the same for Canola flax and Flax_canola samples - but also the kind of supplemented fat. The oil mixtures supplied decreased the color components of the muscle tissue, except for the red component in the treatment with $2 \%$ of canola oil and $1 \%$ of flaxseed oil, where difference was not found compared to the control. The fat source in the meat product may influence tissue color, as observed by Jo et al. (2000) in sausages. However, in that work, fat was added directly to the meat product and not to the forage. Teye et al. (2006a) found no difference in color components of pork longissimus muscle in the meat from animals fed forage with palm kernel oil, palm oil, and soybean oil. These results confirm that the effect on the color of muscle tissue is questionable.

In the present study, color analysis of the fat tissue showed that there was no influence of fat addition to the forage on the color of the fat tissue in Polish Landrace $\mathrm{x}$ Duroc. Similar results were reported by Teye

Table 2. Characteristics of the analyzed smoked pork loin.

\begin{tabular}{|c|c|c|c|c|c|c|c|c|}
\hline \multirow[t]{2}{*}{ Treatment $^{(1)}$} & \multirow[t]{2}{*}{ Selenium $\left(\mu \mathrm{g} 100 \mathrm{~g}^{-1}\right)$} & \multirow[t]{2}{*}{ Fat $\left(\mathrm{g} 100 \mathrm{~g}^{-1}\right)$} & \multicolumn{5}{|c|}{ Fatty acid profile $(\%)$} & \multirow[t]{2}{*}{$n-6 / n-3$ ratio } \\
\hline & & & Saturated & Monounsaturated & Polyunsaturated & PUFA n-3 & PUFA n-6 & \\
\hline & \multicolumn{8}{|c|}{ Polish Landrace } \\
\hline Control & $8.72 \pm 1.0$ & $5.1 \pm 0.9$ & $34.74 \pm 3.2$ & $45.70 \pm 2.9$ & $14.06 \pm 2.2$ & $1.82 \pm 0.4$ & $10.69 \pm 1.2$ & 5.9 \\
\hline Selenium & $13.58 \pm 0.9$ & $4.2 \pm 0.9$ & $37.69 \pm 2.4$ & $41.91 \pm 2.2$ & $14.91 \pm 2.2$ & $2.28 \pm 0.5$ & $13.50 \pm 1.2$ & 5.9 \\
\hline & \multicolumn{8}{|c|}{ Polish Landrace $\mathrm{x}$ Duroc } \\
\hline Control & $7.85 \pm 1.1$ & $5.1 \pm 0.7$ & $39.03 \pm 4.4$ & $40.24 \pm 4.1$ & $15.22 \pm 2.3$ & $3.37 \pm 0.6$ & $14.94 \pm 2.0$ & 4.4 \\
\hline Selenium & $15.93 \pm 1.0$ & $4.4 \pm 0.6$ & $39.81 \pm 3.5$ & $40.88 \pm 2.1$ & $13.81 \pm 2.1$ & $3.21 \pm 0.4$ & $9.91 \pm 1.6$ & 3.1 \\
\hline Canola_flax & $8.28 \pm 0.3$ & $6.3 \pm 0.8$ & $35.95 \pm 4.1$ & $36.56 \pm 3.1$ & $21.98 \pm 2.1$ & $4.42 \pm 0.4$ & $17.66 \pm 2.1$ & 4.0 \\
\hline Flax_canola & $8.78 \pm 0.9$ & $6.1 \pm 0.8$ & $36.64 \pm 3.5$ & $35.21 \pm 3.1$ & $22.65 \pm 2.1$ & $6.31 \pm 0.5$ & $16.71 \pm 1.9$ & 2.6 \\
\hline
\end{tabular}

${ }^{(1)}$ Canola_flax, $2 \%$ of canola oil and $1 \%$ of flaxseed oil in the forage; Flax_canola, $2 \%$ of flaxseed oil and $1 \%$ of canola oil in the forage. PUFA, polyunsaturated fatty acids. 
et al. (2006b), who found no differences in the color components of loin and shoulder fat. Since the color assessment of tissues, in general, is not an easy task, not much research has been carried out on the subject. However, the results of the present work indicate that the color of the fat tissue is less prone to change, when influenced by fatty acid composition, than the color of the muscle tissue.
Results for connective tissue differed from those obtained for fat tissue (Table 3). Each of the fat sources analyzed caused changes in the color components. The color components from animals fed with the supplemented forage were lower than those of the animals fed the control forage. Plant oil supplementation causes color changes mainly due to changes in fatty acid composition, and plant oils are

Table 3. Red, green, and blue color components of muscle tissue, fat tissue, connective tissue, and smoked surface of pork loin of two breeds fed forage supplemented with bioactive components ${ }^{(1)}$.

\begin{tabular}{|c|c|c|c|}
\hline Treatment ${ }^{(2)}$ & Red & Green & Blue \\
\hline & & Muscle tissue & \\
\hline \multicolumn{4}{|l|}{ Polish Landrace } \\
\hline Control & $182.78 \pm 29.38 \mathrm{ab}$ & $130.53 \pm 25.63 \mathrm{ab}$ & $115.29 \pm 25.91 \mathrm{ab}$ \\
\hline Selenium & $193.46 \pm 28.30 \mathrm{cde}$ & $142.33 \pm 22.26 \mathrm{~cd}$ & $125.69 \pm 21.18 \mathrm{~cd}$ \\
\hline \multicolumn{4}{|c|}{ Polish Landrace $\mathrm{x}$ Duroc } \\
\hline Control & $197.96 \pm 28.52 \mathrm{cf}$ & $145.59 \pm 21.25 \mathrm{c}$ & $130.21 \pm 21.76 \mathrm{c}$ \\
\hline Selenium & $177.26 \pm 27.54 \mathrm{a}$ & $125.28 \pm 24.06 \mathrm{a}$ & $110.29 \pm 22.70 \mathrm{a}$ \\
\hline Canola_flax & $187.89 \pm 32.61 \mathrm{bef}$ & $135.81 \pm 29.95 \mathrm{bd}$ & $119.12 \pm 30.57 \mathrm{bd}$ \\
\hline Flax_canola & $183.27 \pm 30.49 \mathrm{abd}$ & $130.61 \pm 26.26 \mathrm{ab}$ & $115.48 \pm 26.44 \mathrm{ab}$ \\
\hline \multirow[t]{2}{*}{$\mathrm{p}$ value of the F test } & 0.0000 & 0.0000 & 0.0000 \\
\hline & & Fat tissue & \\
\hline \multicolumn{4}{|l|}{ Polish Landrace } \\
\hline Control & $220.64 \pm 27.42 \mathrm{a}$ & $176.96 \pm 16.65 \mathrm{a}$ & $158.66 \pm 19.27 \mathrm{a}$ \\
\hline Selenium & $217.38 \pm 28.09 \mathrm{a}$ & $176.22 \pm 19.55 \mathrm{a}$ & $160.16 \pm 22.64 \mathrm{a}$ \\
\hline \multicolumn{4}{|c|}{ Polish Landrace x Duroc } \\
\hline Control & $214.77 \pm 24.99 \mathrm{ab}$ & $176.89 \pm 25.22 \mathrm{a}$ & $159.91 \pm 26.25 \mathrm{a}$ \\
\hline Selenium & $207.33 \pm 29.70 b c$ & $165.91 \pm 23.42 b$ & $148.09 \pm 27.49 b$ \\
\hline Canola_flax & $211.23 \pm 28.90 \mathrm{ab}$ & $173.41 \pm 29.36 \mathrm{ab}$ & $158.77 \pm 31.90 \mathrm{a}$ \\
\hline Flax_canola & $211.65 \pm 26.54 \mathrm{ab}$ & $170.69 \pm 22.53 \mathrm{ab}$ & $154.85 \pm 25.75 \mathrm{ab}$ \\
\hline \multirow[t]{2}{*}{ p value of the F test } & 0.0310 & 0.0031 & 0.0006 \\
\hline & & Connective tissue & \\
\hline \multicolumn{4}{|l|}{ Polish Landrace } \\
\hline Control & $137.36 \pm 23.86 \mathrm{a}$ & $91.82 \pm 15.03 \mathrm{a}$ & $77.39 \pm 14.19 \mathrm{ab}$ \\
\hline Selenium & $136.56 \pm 20.76 a$ & $92.22 \pm 15.69 \mathrm{a}$ & $72.48 \pm 16.79 b c$ \\
\hline \multicolumn{4}{|c|}{ Polish Landrace $\mathrm{x}$ Duroc } \\
\hline Control & $146.57 \pm 28.00 \mathrm{~b}$ & $98.84 \pm 16.28 b$ & $81.10 \pm 14.86 \mathrm{a}$ \\
\hline Selenium & $130.74 \pm 18.79 \mathrm{ac}$ & $87.89 \pm 14.01 \mathrm{ac}$ & $74.08 \pm 14.21 b$ \\
\hline Canola_flax & $134.02 \pm 24.15 \mathrm{ac}$ & $88.64 \pm 15.24 \mathrm{ac}$ & $72.89 \pm 15.02 b c$ \\
\hline Flax_canola & $127.84 \pm 22.08 \mathrm{c}$ & $85.27 \pm 16.41 \mathrm{c}$ & $68.59 \pm 17.74 \mathrm{c}$ \\
\hline \multirow[t]{2}{*}{$\mathrm{p}$ value of the $\mathrm{F}$ test } & 0.0000 & 0.0000 & 0.0363 \\
\hline & & Smoked surface & \\
\hline \multicolumn{4}{|l|}{ Polish Landrace } \\
\hline Control & $118.03 \pm 20.10 \mathrm{a}$ & $50.37 \pm 13.24 \mathrm{ab}$ & $17.33 \pm 7.94 \mathrm{a}$ \\
\hline Selenium & $132.93 \pm 26.72 b c$ & $60.92 \pm 19.84 \mathrm{c}$ & $20.72 \pm 12.43 \mathrm{a}$ \\
\hline \multicolumn{4}{|c|}{ Polish Landrace $\mathrm{x}$ Duroc } \\
\hline Control & $135.98 \pm 30.95 b$ & $61.50 \pm 15.91 \mathrm{c}$ & $19.02 \pm 8.76 \mathrm{a}$ \\
\hline Selenium & $126.85 \pm 21.70 \mathrm{ab}$ & $57.47 \pm 14.58 \mathrm{bc}$ & $20.04 \pm 12.91 \mathrm{a}$ \\
\hline Canola_flax & $121.72 \pm 28.01 \mathrm{ac}$ & $55.52 \pm 16.61 \mathrm{bc}$ & $18.92 \pm 6.98 \mathrm{a}$ \\
\hline Flax_canola & $123.86 \pm 28.72 \mathrm{ab}$ & $56.63 \pm 20.41 \mathrm{bc}$ & $21.14 \pm 16.06 \mathrm{a}$ \\
\hline $\mathrm{p}$ value of the F test & 0.0000 & 0.0000 & 0.3220 \\
\hline
\end{tabular}

${ }^{(1)}$ Means \pm SD followed by equal letters, in the columns, do not differ by Scheffe's post hoc test, at $5 \%$ probability. ${ }^{(2)}$ Canola flax, $2 \%$ of canola oil and $1 \%$ of flaxseed oil in the forage; Flax_canola, $2 \%$ of flaxseed oil and $1 \%$ of canola oil in the forage. 
generally rich in unsaturated fatty acids, which causes them to be more susceptible to oxidation and to have a reduced shelf-life (Rosenvold \& Andersen, 2003).

Similarly to the fat tissue, in the smoked loin surface, the color of samples from supplemented animals did not differ from that of the control (Table 3). However, the mixture with $2 \%$ of canola oil and $1 \%$ of flaxseed oil in the forage showed significant difference for the red component in the comparison with control sample. Therefore, it may be concluded that the forage with a mixture of $2 \%$ of canola oil and $1 \%$ of flaxseed oil has specific influence on the red color component of the muscle tissue (inside the sample or smoked surface), unlike the mixture of $2 \%$ of flaxseed oil and $1 \%$ of canola oil. This is possibly associated with the fatty acid composition of the oil mixtures.

When treating both controls as the market product, the most important differences as to color of samples were found for fat and connective tissues. Therefore, Polish Landrace $\mathrm{x}$ Duroc feeding forage supplemented with selenium may be associated with different color of fat tissue in comparison to that of the market products. Moreover, when feeding forage supplemented with $2 \%$ of flaxseed oil and 1\% of canola oil, this breed may have connective tissue with different color than that of the market products. However, further research is still needed to analyze consumer perception of these products.

\section{Conclusions}

1. The color components of muscle, fat, connective tissues, and smoked loin surface depend on the pig breed and on the bioactive compounds added to the forage.

2. Selenium supplementation causes higher color components for the Polish Landrace breed, and lower ones for the Polish Landrace $\mathrm{x}$ Duroc crossbreed.

3. The color components of the fat tissue are less prone to change with the supplementation of bioactive products than the ones of connective and muscle tissues.

4. Oil supplementation is associated with lower values of color components for the Polish Landrace $\mathrm{x}$ Duroc crossbreed.

5. Selenium or oil supplementation with $2 \%$ of flaxseed oil and $1 \%$ of canola oil may be associated with different color of fat and connective tissue of the Polish Landrace $\mathrm{x}$ Duroc breed compared to the market products.

\section{Acknowledgements}

To the European Regional Development Fund, within the Innovative Economy Operational Programme (2007-2013) of the European Union, for financial support within Biofood; and to the Embassy of the Federal Republic of Brazil and to Almir Gonçalves, for support.

\section{References}

ALDERMAN, G. Prediction of the energy value of compound feeds. In: HARESIGN, W.; COLE, D.J.A. (Ed.). Recent advances in animal nutrition. London: Butterworths, 1985. p.3-53.

BHAT, Z.F.; BHAT, H. Functional meat products: a review. International Journal of Meat Science, v.1, p.1-14, 2011.

CUNIFF, P. Official methods of analysis of AOAC International. $16^{\text {th }}$ ed. Gaithersburg: AOAC International, 1997. $2 \mathrm{v}$.

DOYON, M.; LABRECQUE, J. Functional foods: a conceptual definition. British Food Journal, v.110, p.1133-1149, 2008.

FOLCH, J.; LEES, M.; STANLEY, G.H.S. A simple method for the isolation and purification of total lipids from animal tissues. The Journal of Biological Chemistry, v.226, p.497-509, 1957.

GRUNERT, K.G.; BREDAHL, L.; BRUNS $\varnothing$, K. Consumer perception of meat quality and implications for product development in the meat sector - a review. Meat Science, v.66, p.259-272, 2004.

GUZEK, D.; GŁĄBSKA, D.; WIERZBICKA, A. Analysis of beef topside RGB components of colour after thermal treatment executed in the steam-convection oven, on the basis of fresh meat colour. Journal of Research and Applications in Agricultural Engineering, v.57, p.55-58, 2012.

INTERNATIONAL ORGANIZATION FOR STANDARDIZATION. ISO 1444: meat and meat products - determination of fat-free content. Geneva: ISO, 2000. 7p.

IQBAL,A.; VALOUS, N.A.; MENDOZA, F.; SUN, D.-W.; ALLEN, P. Classification of pre-sliced pork and Turkey ham qualities based on image colour and textural features and their relationships with consumer responses. Meat Science, v.84, p.455-465, 2010.

JIMÉNEZ-COLMENERO, F.; SÁNCHEZ-MUNIZ, F.J.; OLMEDILLA-ALONSO, B.; AYO, J.; CARBALLO, J.; COFRADES, S.; RUIZ-CAPILLAS, C.; SERRANO, A. Design and development of meat-based functional foods with walnut: technological, nutritional and health impact. Food Chemistry, v.123, p.959-967, 2010.

JO, C.; JIN, S.K.; AHN, D.U. Color changes in irradiated cooked pork sausage with different fat sources and packaging during storage. Meat Science, v.55, p.107-113, 2000.

JOSQUIN, N.M.; LINSSEN, J.P.H.; HOUBEN, J.H. Quality characteristics of Dutch-style fermented sausages manufactured with partial replacement of pork back-fat with pure, pre-emulsified or encapsulated fish oil. Meat Science, v.90, p.81-86, 2012.

JOY, M.; RIPOLL, G.; MOLINO, F.; DERVISHI, E.; ÁLVAREZ-RODRIGUEZ, J. Influence of the type of forage 
supplied to ewes in pre- and post-partum periods on the meat fatty acids of suckling lambs. Meat Science, v.90, p.775-782, 2012.

JUÁREZ, M.; DUGAN, M.E.R.; ALDAI, N.; AALHUS, J.L.; PATIENCE, J.F.; ZIJLSTRA, R.T.; BEAULIEU, A.D. Feeding co-extruded flaxseed to pigs: effects of duration and feeding level on growth performance and backfat fatty acid composition of grower-finisher pigs. Meat Science, v.84, p.578-584, 2010.

KAPSAK, W.R.; RAHAVI, E.B.; CHILDS, N.M.; WHITE, C. Functional foods: consumer attitudes, perceptions, and behaviors in a growing market. Journal of the American Dietetic Association, v.111, p.804-810, 2011.

KRAUSE, B.; MANDIGO, R.; BURSON, D. The effect of organic and inorganic selenium on smoked pork chop color. Nebraska Swine Report, v.1, p.36-38, 2007.

MAHAN, D.C.; BRENDEMUHL, J.H.; CARTER, S.D.; CHIBA, L.I.; CRENSHAW, T.D.; CROMWELL, G.L.; DOVE, C.R.; HARPER, A.F.; HILL, G.M.; HOLLIS, G.R.; KIM, S.W.; LINDEMANN, M.D.; MAXWELL, C.V.; MILLER, P.S.; NELSSEN, J.L.; RICHERT, B.T.; SOUTHERN, L.L.; STAHLY, T.S.; STEIN, H.H.; HEUGTEN, E.; YEN J.T. Comparison of dietary selenium fed to grower-finisher pigs from various regions of the United States on resulting tissue Se and loin mineral concentrations. Journal of Animal Science, v.83, p.852-857, 2005.

MAHAN, D.C.; CLINE, T.R.; RICHERT, B. Effects of dietary levels of selenium-enriched yeast and sodium selenite as selenium sources fed to growing-finishing pigs on performance, tissue selenium, serum glutathione peroxidase activity, carcass characteristics, and loin quality. Journal of Animal Science, v.77, p.2172-2179, 1999.

MATEO, R.D.; SPALLHOLZ, J.E.; ELDER, R.; YOON, I.; KIM, W. Efficacy of dietary selenium sources on growth and carcass characteristics of growing-finishing pigs fed diets containing high endogenous selenium. Journal of Animal Science, v.85, p.1177-1183, 2007.

MORIN, L.A.; TEMELLI, F.; MCMULLEN, L. Interactions between meat proteins and barley (Hordeum spp.) $\beta$-glucan within a reduced-fat breakfast sausage system. Meat Science, v.68, p.419-430, 2004.

POLYCHRONOPOULOS, E.; POUNIS, G.; BOUNTZIOUKA, V.; ZEIMBEKIS, A.; TSILIGIANNI, I.; QIRA, B.-E.; GOTSIS, E.; METALLINOS, G.; LIONIS, C.; PANAGIOTAKOS, D. Dietary meat fats and burden of cardiovascular disease risk factors, in the elderly: a report from the MEDIS study. Lipids in Health and Disease, v.9, p.30-35, 2010.

POOVEY, K.A.; BURSON, D.E.; BATIE, A.K.; JENSCHKE, B.E.; MILLER, P.S. The effect of dietary selenium on pork carcass quality and longissimus color stability. Nebraska Swine Report, v.1, p.32-35, 2007.

ROSENVOLD, K.; ANDERSEN, H.J. Factors of significance for pork quality - a review. Meat Science, v.64, p.219-237, 2003.

SINGH, P.N.; SABATÉ, J.; FRASER, G.E. Does low meat consumption increase life expectancy in humans? American Journal of Clinical Nutrition, v.78, p.526-532, 2003.

SIRÓ, I.; KÁPOLNA, E.; KÁPOLNA, B.; LUGASI, A. Functional food. Product development, marketing and consumer acceptance a review. Appetite, v.51, p.456-467, 2008.

SVOBODA, M.; SALÁKOVÁ, A.; FAJT, Z.; KOTRBÁČEK, V.; FICEK, R.; DRÁBEK, J. Efficacy of Se-enriched alga Chlorella spp. and Se-enriched yeast on tissue selenium retention and carcass characteristics in finisher pigs. Acta Veterinaria Brno, v.78, p.579-587, 2009.

TAN, J.L. Meat quality evaluation by computer vision. Journal of Food Engineering, v.61, p.27-35, 2004.

TEYE, G.A.; SHEARD, P.R.; WHITTINGTON, F.M.; NUTE, G.R.; STEWART, A.; WOOD, J.D. Influence of dietary oils and protein level on pork quality. 1. Effects on muscle fatty acid composition, carcass, meat and eating quality. Meat Science, v.73, p.157-165, 2006a.

TEYE, G.A.; WOOD, J.D.; WHITTINGTON, F.M.; STEWART, A.; SHEARD, P.R. Influence of dietary oils and protein level on pork quality. 2. Effects on properties of fat and processing characteristics of bacon and frankfurter-style sausages. Meat Science, v.73, p.166-177, 2006b.

VERBEKE, W. Functional foods: consumer willingness to compromise on taste for health? Food Quality and Preference, v.17, p.126-131, 2006.

ZHAN, X.A.; WANG, M.; ZAHO, R.Q.; LI, W.; XU, Z. Effects of selenium source on selenium distribution, loin quality and antioxidant status in finishing pigs. Animal Feed Science and Technology, v.132, p.202-211, 2007.

ZHENG, C.; SUN, D.-W.; ZHENG, L. Correlating colour to moisture content of large cooked beef joints by computer vision. Journal of Food Engineering, v.77, p.858-863, 2006.

Received on May 31, 2012 and accepted on September 11, 2012 